\title{
Pratique ethnographique et technologie culturelle
}

\section{Serge Tornay}

\section{OpenEdition}

Journals

Édition électronique

URL : https://journals.openedition.org/tc/1010

DOI : $10.4000 /$ tc. 1010

ISSN : 1952-420X

\section{Éditeur}

Éditions de l'EHESS

\section{Édition imprimée}

Date de publication : 1 juin 1984

ISSN : 0248-6016

\section{Référence électronique}

Serge Tornay, «Pratique ethnographique et technologie culturelle», Techniques \& Culture [En ligne], 3 | 1984, mis en ligne le 26 janvier 2006, consulté le 29 septembre 2022. URL : http:// journals.openedition.org/tc/1010; DOI : https://doi.org/10.4000/tc.1010

Ce document a été généré automatiquement le 29 septembre 2022.

Tous droits réservés 


\title{
Pratique ethnographique et technologie culturelle
}

\author{
Serge Tornay
}

